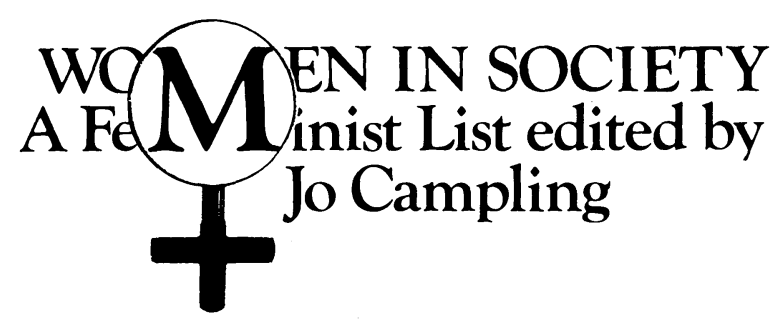

editorial advisory group

Maria Brenton, University College, Cardiff; Phillida Buckle, Victoria University, Wellington, New Zealand; Leonore Davidoff, University of Essex; Janet Finch, University of Lancaster; Jalna Hanmer, University of Bradford; Beverley Kingston, University of New South Wales, Australia; Hilary Land, University of Bristol; Diana Leonard, University of London Institute of Education; Susan Lonsdale, Polytechnic of the South Bank; Jean O'Barr, Duke University, North Carolina, USA; Arlene Tigar McLaren, Simon Fraser University, British Columbia, Canada; Jill Roe, Macquarie University, Australia ; Pat Thane, Goldsmiths' College, University of London; Jane Thompson, University of Southampton; Clare Ungerson, University of Kent at Canterbury; Judy Walkowitz, Rutgers University, New Jersey, USA.

The 1970s and 1980s have seen an explosion of publishing by, about and for women. This new list is designed to make a particular contribution to this process by commissioning and publishing books which consolidate and advance feminist research and debate in key areas in a form suitable for students, academics and researchers but also accessible to a broader general readership.

As far as possible books will adopt an international perspective incorporating comparative material from a range of countries where this is illuminating. Above all they will be interdisciplinary, aiming to put women's studies and feminist discussion firmly on the agenda in subject-areas as disparate as law, physical education, art and social policy. 


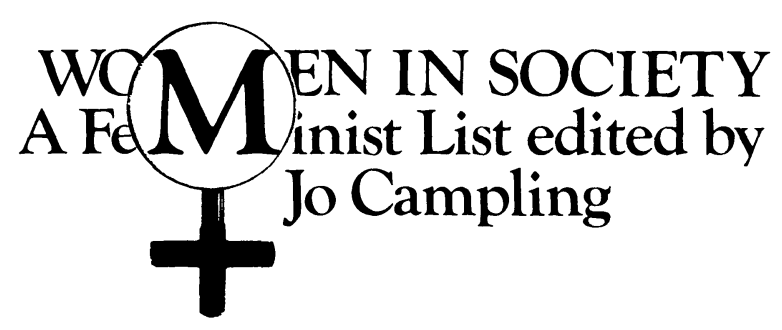

Published

The Family in Question: changing households and familiar ideologies

Diana Gittins

Women and Crime

Frances Heidensohn

Passbook Number F.47927: women and Mau Mau in Kenya Muthoni Likimani (Introductory Essay by Jean O'Barr)

Women and Social Policy: a reader

Clare Ungerson (editor)

\author{
Forthcoming \\ Women in Ireland \\ Jenny Beale \\ Ideologies of Caring \\ Gillian Dalley
}

Our Work, Our Lives, Our Words: women's history and

women's work

Leonore Davidoff and Belinda Westover (editors)

Women and Sport

Jennifer Hargreaves

Women and Spirituality

Ursula King

Marriage and Money

Jan Pahl

Living with Conflict

Rosemary Ridd (editor)

Women's Family Lives

Lesley Rimmer

The Art of Women

Janet Wolff 


\section{Women and Social Policy}

A Reader

Edited by

Clare Ungerson

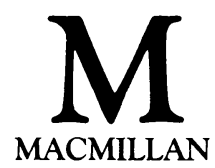


Selection and editorial matter (C) Clare Ungerson 1985

Softcover reprint of the hardcover 1st edition 1985 978-0-333-36725-4

The Acknowledgements page constitutes a continuation of this copyright page.

All rights reserved. No reproduction, copy or transmission of this publication may be made without written permission.

No paragraph of this publication may be reproduced, copied or transmitted save with written permission or in accordance with the provisions of the Copyright Act 1956 (as amended).

Any person who does any unauthorised act in relation to this publication may be liable to criminal prosecution and civil claims for damages.

First published 1985

Published by

Higher and Further Education Division

MACMILLAN PUBLISHERS LTD

Houndmills, Basingstoke, Hampshire RG21 2XS

and London

Companies and representatives

throughout the world

Filmsetting by Vantage Photosetting Co Ltd,

Eastleigh and London

British Library Cataloguing in Publication Data

Women and social policy.-(Women in society)

1. Women - Great Britain-Social conditions

I. Ungerson, Clare II. Series

305.4'2'0941 HQ1593

ISBN 978-0-333-36726-1

ISBN 978-1-349-17956-5 (eBook)

DOI 10.1007/978-1-349-17956-5 


\section{Contents}

Preface vii

Acknowledgements $\quad$ ix

Section I WOMEN AND SOCIAL SECURITY

A. Motherhood

Introduction

Hilary Land The Introduction of Family

Allowances: an Act of Historic Justice?

The Family Allowance Campaign Family

Allowance

Zoë Fairbairns The Wrong Rats

B. Marriage

Introduction

Hilary Land Who Still Cares for the Family? Recent

Developments in Income Maintenance

Zoë Fairbairns The Cohabitation Rule - Why It

Makes Sense

David Donnison The Cohabitation Rule

\section{Section II WOMEN AND HOUSING POLICY}

Introduction

Helen Austerberry and Sophie Watson A Woman's Place: a Feminist Approach to Housing in Britain

Marilyn French The Women's Room

Ken Coates and Richard Silburn Housework in a Slum 
vi Contents

Section III WOMEN AND EDUCATION POLICY

Introduction

Rosemary Deem State Policy and Ideology in the Education of Women, 1944-1980

Michelle Stanworth 'Just Three Quiet Girls'

Section IV WOMEN AND HEALTH CARE POLICY

Introduction

Lesley Doyal Women and the Crisis in the National

Health Service

Malcolm Potts, Peter Diggory and John Peel The

Working of the 1967 Abortion Act in Britain

Sally Macintyre Gynaecologist/Woman Interaction

Section V WOMEN AND THE PERSONAL SOCIAL SERVICES

Introduction

Jeff Hearn Patriarchy, Professionalisation and the Semi-Professions

\section{Section VI WOMEN AND THE INFORMAL AND VOLUNTARY SECTOR OF THE SOCIAL SERVICES}

Introduction

Margaret Thatcher 'Facing the New Challenge'

Janet Finch and Dulcie Groves Community Care and the Family: A Case for Equal Opportunities?

Hilary Rose Women's Refuges: Creating New Forms of Welfare?

Bibliography 


\section{Preface}

While preparing a course on 'Women and Social Policy' at the University of Kent I realised that the literature in this area of Social Administration and Women's Studies was still widely scattered across a range of journals, government reports and books (fiction and non-fiction), such that it was practically impossible for any student, let alone teacher, to find everything they needed for an adequate grasp of the issues across all the social services. This book is designed to bring some of those scattered readings together in such a way that the relationship between women and each of the five social policy areas, namely social security, housing, education, health and the personal social services, is clarified. Each section of the book deals with one of these five areas. The final section deals with women's relationship to the fast-growing area of social service provision in the voluntary and informal sectors.

The sections of the book (and the two sub-sections) are each prefaced by a short introduction written by myself. These introductions are designed to do three things: first, to make sense of the particular readings I have chosen for the section; second, to introduce the literature pertinent to each policy area; and third, to outline some - though by no means all - the issues that arise out of each set of readings. Since each of the introductions is specifically designed to introduce further reading on the topic, readers should use the full bibliography at the end of the book to build up their reading lists. Where $I$ have been unable to weave all the important and relevant reading into the thread of the argument, I have appended a brief note on additional reading to each of the introductions.

It is my hope that each section will spark off far more ideas than I have had the space to develop here. It is partly for that reason that most of the introductions are deliberately left open-ended. But there is also an intellectual reason: it seems to me that there are dilemmas for women contained within each social service area 
which are extremely difficult to resolve. Again, I hope that the posing of unresolved questions will lead to further discussion among students and teachers alike. There are also two issues which, for reasons of space, have not been discussed at length. Class relations and race relations form much of the context for discussion of the relationship between women and social policy, but to cover them fully would have needed a second book.

I first started to think about teaching a course on 'Women and Social Policy' arranged in this way when, in 1981, I spent a semester at the Department of Political Science at the University of Massachusetts, Amherst. My grateful thanks are due to the small group of students who attended that embryonic course and who, with their enthusiasm, convinced me that here was a course that was worth developing. Subsequently, at the University of Kent, I have taught a course of that name on the MA in Women's Studies and on the undergraduate degree in Social Administration. Members of the Women's Studies Committee, particularly Mary Evans and Janet Sayers, have been of immense help to me in very many ways, both as colleagues and as friends. Sarah Carter, Assistant Librarian at the University of Kent, recognised in its very early days the great importance of academic feminism, and, largely through her efforts, the University now has an excellent collection of feminist writing which I have found invaluable. Members of the Board of Studies in Social Policy and Administration, particularly John Baldock, Nick Manning and Peter Taylor-Gooby, each of whom have contributed to the course, have also been extremely helpful. And, last but not least, I must thank, for their responsiveness and confidence, the MA students and undergraduates at the University of Kent who have taken this course over the past three years.

A number of people have helped me directly with this book by commenting on the introductions. They are: David Donnison, Vic George, Hilary Land, Nick Manning, Chris Pickvance, Marion Roberts and Janet Sayers. I am very grateful to all of them; they are, of course, not responsible for what remains. Jo Campling, the editor of this list, was always at the end of the telephone with supportive and soothing words. Finally, I am deeply grateful to William Fortescue for all his support - practical and otherwise. 


\section{Acknowledgements}

The author and publishers wish to thank the following who have kindly given permission for the use of copyright material:

Edward Arnold for an extract from 'In Practice Supported, In Theory Denied' by Hilary Rose in International Journal of Urban and Regional Research, Vol. 2, No. 3 (1978).

Helen Austerberry and Sophie Watson for 'A Woman's Place: A Feminist Approach to Housing in Britain' first published in Feminist Review, No. 8 (1981).

The British Sociological Association for extracts from 'Notes on Patriarchy, Professionalization and the Semi-Professions' by Jeff Hearn which first appeared in Sociology, Vol. 16, No. 2 (1982).

Cambridge University Press for an extract from 'The Working of the 1967 Abortion Act in Britain' by M. Potts, P. Diggory and J. Peel in Abortion (1977); and an extract from 'Community Care and the Family: A Case for Equal Opportunities?' in Journal of Social Policy by J. Finch and D. Groves (Vol. 9, Part 4, October 1984).

Carfax Publishing Company Ltd for an extract from 'State Policy and Ideology in the Education of Women, 1944-1980, by Rosemary Deem in British Journal of Sociology of Education, Vol.2, No. 2 (1981).

Critical Social Policy Ltd for an extract from 'Women, Health and the Sexual Division of Labour' by Lesley Doyal in Women's Health Movement, Critical Social Policy, Issue 7 (1983).

Croom Helm Ltd for an extract from Women's Welfare, Women's Rights by Hilary Land; and an extract from Single and Pregnant by Sally McIntyre.

Andre Deutsch Ltd for an extract from The Women's Room by Marilyn French. 


\section{x Acknowledgements}

A. M. Heath \& Co. Ltd on behalf of Zoë Fairbairns for 'The Cohabitation Rule' first published in Women's Studies International, Quarterly, Vol. 2 (1979).

Heinemann Educational Books Ltd for an extract from Change, Choice and Conflict in Social Policy by P. Hall, H. Land, A. Webb and R. Parker.

The Controller of Her Majesty's Stationery Office for an extract from the evidence submitted by the Family Allowances Campaign to the Select Committee on Tax Credit (1973).

Hutchinson Ltd for an extract from Gender and Schooling by Michelle Stanworth (1981).

Martin Robertson \& Co. Ltd for an extract from 'The Politics of Poverty' in Women and Social Policy by David Donnison (1982).

Spokesman for an extract from Poverty: The Forgotten Englishmen by Ken Coates and Richard Silburn.

Margaret Thatcher for an extract from her speech to the WRVS National Conference (1981).

Virago Press Ltd for an extract from Benefits: A Novel by Zoë Fairbairns.

Every effort has been made to trace all the copyright holders, but if any have been inadvertently overlooked the publishers will be pleased to make the necessary arrangements at the first opportunity. 